\title{
Tumour necrosis factor- $\alpha$ is the signal induced by mating to shutdown a 2-methoxyestradiol nongenomic action necessary to accelerate oviductal egg transport in the rat
}

\author{
María L Oróstica ${ }^{1,2}$, Lidia M Zuñiga ${ }^{3}$, Daniella Utz ${ }^{1}$, Alexis Parada-Bustamante ${ }^{3}$, \\ Luis A Velásquez ${ }^{2,4}$, Hugo Cardenas ${ }^{1,2}$ and Pedro A Orihuela ${ }^{1,2}$ \\ ${ }^{1}$ Laboratorio de Inmunología de la Reproducción, Facultad de Química y Biología, Universidad de Santiago de Chile, \\ Alameda 3363, Casilla 40, Correo 33, Santiago, Chile, ${ }^{2}$ Centro para el Desarrollo en Nanociencia y Nanotecnología, \\ CEDENNA, Santiago, Chile, ${ }^{3}$ Millennium Institute for Fundamental and Applied Biology, Santiago, Chile and \\ ${ }^{4}$ Facultad de Medicina, Center for Integrative Medicine and Innovative Science, Universidad Andres Bello, \\ Santiago, Chile
}

Correspondence should be addressed to P A Orihuela at Laboratorio de Inmunología de la Reproducción, Facultad de Química y Biología, Universidad de Santiago de Chile; Email: pedro.orihuela@usach.cl

\begin{abstract}
Mating shut down a 2-methoxyestradiol (2ME) nongenomic action necessary to accelerate egg transport in the rat oviduct. Herein, we investigated whether tumour necrosis factor- $\alpha$ (TNF- $\alpha$ ) participates in this mating effect. In unmated and mated rats, we determined the concentration of TNF- $\alpha$ in the oviductal fluid and the level of the mRNA for Tnf-a (Tnf) and their receptors Tnfrsf1a and Tnfrsf1b in the oviduct tissues. The distribution of the TNFRSF1A and TNFRSF1B proteins in the oviduct of unmated and mated was also assessed. Finally, we examined whether $2 \mathrm{ME}$ accelerates oviductal egg transport in unmated rats that were previously treated with a rat recombinant TNF- $\alpha$ alone or concomitant with a selective inhibitor of the NF- $\kappa$ B activity. Mating increased TNF- $\alpha$ in the oviductal fluid, but $T n f$ transcript was not detected in the oviduct. The mRNA for TNF- $\alpha$ receptors as well as their distribution was not affected by mating, although they were mainly localized in the endosalpinx. Administration of TNF- $\alpha$ into the oviduct of unmated rats prevented the effect of $2 \mathrm{ME}$ on egg transport. However, the NF- $\kappa$ B activity inhibitor did not revert this effect of TNF- $\alpha$. These results indicate that mating increased TNF- $\alpha$ in the oviductal fluid, although this not associated with changes in the expression and localization of TNF- $\alpha$ receptors in the oviductal cells. Furthermore, TNF- $\alpha$ mimicked the effect of mating on the $2 \mathrm{ME}$-induced egg transport acceleration, independently of the activation of NF-KB in the oviduct. We concluded that TNF- $\alpha$ is the signal induced by mating to shut down a 2 ME nongenomic action in the rat oviduct.
\end{abstract}

Reproduction (2013) 145 109-117

\section{Introduction}

Mating components include sensory stimulation, seminal plasma and spermatozoa. Either individually or collectively, these constituents impact the female physiology through their interaction with cells composing the female reproductive tract. It is now widely accepted that, independently of its fertilizing role, mating has physiological relevance as it affects at molecular and cellular levels the functioning of reproductive organs near or beyond to the site of insemination (Erskine 1995, Robertson 2005).

The relevance of mating-associated factors on the molecular and cellular changes occurring in the female reproductive organs is clearly illustrated by the fact that mating can regulate the role of oestradiol $\left(E_{2}\right)$ and 2-methoxyestradiol (2ME) on the oviductal egg transport in the rat. In unmated rats, $E_{2}$ accelerates ovum transport via a nongenomic action that requires prior conversion of $\mathrm{E}_{2}$ to $2 \mathrm{ME}$ and successive activation of oestrogen receptors (ERs), cAMP-PKA and PLC-IP3 signalling cascades in the oviduct (Orihuela et al. 2001, 2003, 2006, 2009, Parada-Bustamante et al. 2003, 2007). This is corroborated by the fact that $2 \mathrm{ME}$ accelerates oviductal egg transport in unmated rats, but not in mated rats (Parada-Bustamante et al. 2007, 2010). Thus, mating shut down a nongenomic action of $2 \mathrm{ME}$ in the oviduct of unmated rats that is necessary to accelerate egg transport. In mated rats, $E_{2}$ accelerates embryo transport via a genomic action that does not require conversion of $E_{2}$ to $2 \mathrm{ME}$ but involve activation of the ER and signalling of connexin 43, s100g and endothelin in the oviduct (Ríos et al. 2007, 2011, Parada-Bustamante et al. 2012).

Female immune system can recognize and respond to mating-associated signals inducing an inflammatory 
response in the genital tract that involves secretion of granulocyte-macrophage colony-stimulating factor, interleukins and chemokines (O'Leary et al. 2004, Robertson 2005, Kapelnikov et al. 2008). These effects may involve a direct interaction between the cells of the female reproductive tract and the different components of the seminal plasma and/or spermatozoa to modulate the immune system resulting in cellular and molecular changes along the female reproductive tract (reviewed in Sharkey et al. (2007)). Tumour necrosis factor- $\alpha$ (TNF- $\alpha$ ) is a cytokine associated with immune responses in the female genital tract (Tremellen et al. 1998, Maisey et al. 2003, Morales et al. 2006). Furthermore, transcripts of TNF- $\alpha$ and their receptors are expressed in mice, bovine and human oviduct (Hunt et al. 1993, Srivastava et al. 1996, Wijayagunawardane et al. 2003, Reyes et al. 2007). Moreover, there are data showing that TNF- $\alpha$ could participate in reproductive functions including fertilization, embryo development and implantation (Rasmussen et al. 1999, Lee et al. 2000, Torchinsky et al. 2003, Abdo et al. 2008, Choo et al. 2011). Herein, we determined whether TNF- $\alpha$ is associated with the effect of mating on the nongenomic action of $2 \mathrm{ME}$ in the rat oviduct. First, we measured the concentration of TNF- $\alpha$ in the oviductal fluid of unmated and mated rats. We also determined the effect of mating on the levels of mRNA for TNF- $\alpha$ and their receptors Tnfrsfia and Tnfrsf $1 b$ in the endosalpinx and myosalpinx of the rat oviduct. The tissue distribution of TNFRSF1A and TNFRSF1B was then compared in the oviduct of unmated and mated rats. Finally, we determined whether $2 \mathrm{ME}$ accelerates oviductal egg transport in unmated rats previously treated with a local injection of recombinant TNF- $\alpha$ alone or in combination with a selective inhibitor of the NF- $\kappa B$ activity.

\section{Results}

\section{Mating increased the concentration of TNF- $\alpha$ in the oviductal fluid}

This experiment was designed to determine whether mating affects the level of TNF- $\alpha$ in the oviductal fluid. At $0000 \mathrm{~h}$ of day 1 of cycle, a total of 30 rats were kept isolated (unmated group) or caged with fertile males during $30 \mathrm{~min}$ (mated group), and 1,3 or $6 \mathrm{~h}$ later, oviducts were excised and the oviductal fluid was obtained to measure the concentration of TNF- $\alpha$ as described in the Materials and Methods section. Replicas of this experiment are stated in Fig. 1.

Results of this experiment are shown in Fig. 1. In unmated rats, the amount of TNF- $\alpha$ in the oviductal fluid ranged from $0.12 \pm 0.04$ to $0.18 \pm 0.05 \mathrm{pg} / \mu \mathrm{g}$ protein. In mated rats, the amount of TNF- $\alpha$ increased five to six times only $3 \mathrm{~h}$ after mating $(0.72 \pm 0.1 \mathrm{pg} / \mu \mathrm{g}$ protein) whereas 1 and $6 \mathrm{~h}$ post-mating the amount of TNF- $\alpha$ was similar to unmated rats $(1 \mathrm{~h}, 0.19 \pm 0.04 \mathrm{pg} / \mu \mathrm{g}$ protein and $6 \mathrm{~h}, 0.18 \pm 0.01 \mathrm{pg} / \mu \mathrm{g}$ protein).

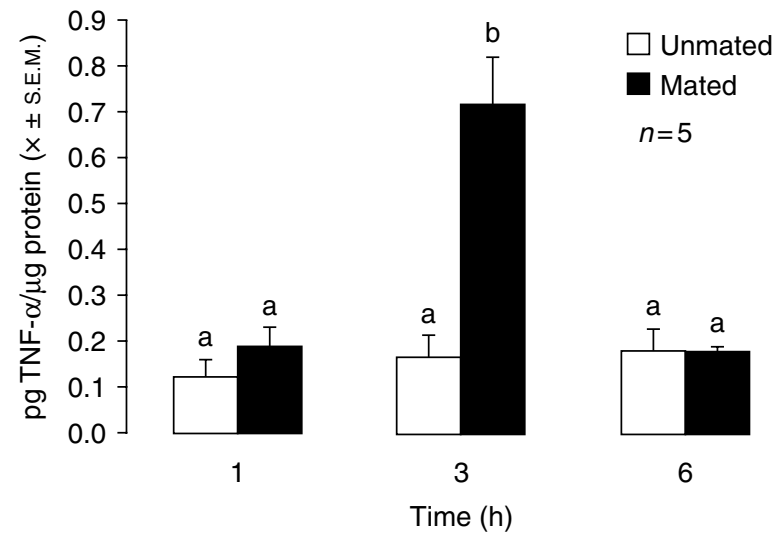

Figure 1 Levels of TNF- $\alpha$ in the oviductal fluid of unmated or mated rats. Rats at $0000 \mathrm{~h}$ of day 1 of the cycle were kept isolated as unmated group or caged with fertile males for 30 min as mated group, and 1, 3 or $6 \mathrm{~h}$ later, animals were autopsied to measure the amount of TNF- $\alpha$ in the oviductal fluid. This experiment consisted of five replicates. $a \neq b$, $P<0.05$. Note a dramatical increase in the amount of TNF- $\alpha 3 \mathrm{~h}$ after mating.

\section{Mating did not change the level of the transcripts of Tnf, Tnfrsf1 a and Tnfrsf $1 \mathrm{~b}$ in the rat oviduct}

This experiment determined whether mating changes the level of mRNA for $\operatorname{Tnf}-\mathrm{a}(\operatorname{Tnf})$ and their receptors Tnfrsf1a and Tnfrsf $1 b$ in the rat oviduct. A total of 60 rats on day 1 of cycle were kept isolated (unmated group) or caged with fertile males during 30 min (mated group), and 1,3 or 6 h later, oviducts were excised and separated in endosalpinx and myosalpinx to measure the level of the transcripts as described. Replicas of this experiment are stated in Figs 2 and 3.

Expression of Tnf mRNA was not detected in the endosalpinx and myosalpinx of unmated and mated rats (data not shown). As a proof of the efficiency of the realtime-PCR for Tnf, we used the RNA from liver samples of unmated rats. A band of 180 bp was detected corresponding to $\operatorname{Tnf}$ as verified after sequencing it (data not shown). On the other hand, the mRNA levels of Tnfrsf1a and Tnfrsf1 $b$ were not different between the endosalpinx (Tnfrsf1a, 30 $\pm 0.03-42 \pm 0.042$ and Tnfrsf1b, $0.12 \pm 0.03-0.22 \pm 0.08$ ) and myosalpinx (Tnfrsf1a, $22 \pm 4.8-30 \pm 5.6$ and Tnfrsf1b, $0.32 \pm 0.08-$ $0.61 \pm 0.24)$ of unmated and mated rats. However, it was clear that the transcript of Tnfrsf1a was more highly expressed than Tnfrsf $1 b$ in the oviducts of unmated and mated rats (Figs 2 and 3).

\section{Mating did not change the tissue distribution of TNF- $\alpha$ receptors in the rat oviduct}

Here, we investigated the tissue distribution of TNFRSF1A and TNFRSF1B in the oviduct of unmated and mated rats. A total of 12 rats on day 1 of cycle were 

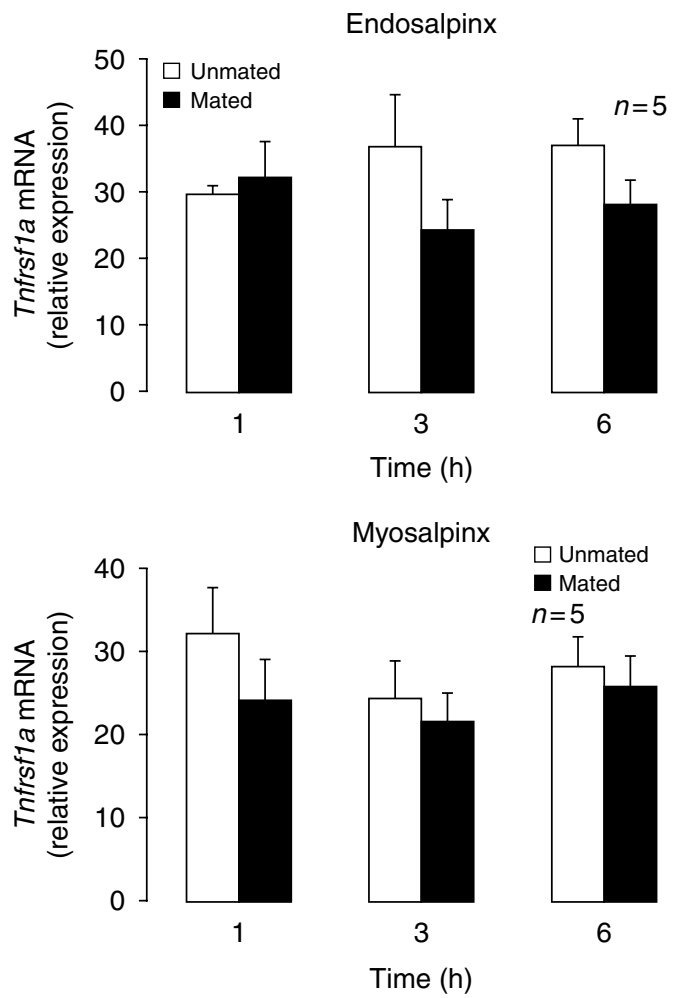

Figure 2 mRNA levels of Tnfrsf1a in the oviduct of unmated or mated rats. Rats at $0000 \mathrm{~h}$ of day 1 of the cycle were kept isolated as unmated group or caged with fertile males for $30 \mathrm{~min}$ as mated group, and 1, 3 or $6 \mathrm{~h}$ later, the endosalpinx and myosalpinx layers were separated from the oviducts to determine the Tnfrsf1a mRNA relative expression obtained through real-time PCR. The values were normalized to Gapdh. This experiment consisted of five replicates. No differences were found between treatment groups.

kept isolated or caged with fertile males during $30 \mathrm{~min}$, and 1 or $3 \mathrm{~h}$ later, oviducts were excised and processed by immunohistochemistry as described. Replicas of this experiment are stated in Figs 4 and 5. Immunoreactivity of TNFRSF1A and TNFRSF1B was detected in the endosalpinx and myosalpinx with no differences in their distribution between the oviducts of unmated and mated (Figs 4 and 5).

\section{TNF- $\alpha$ blocks the 2ME-induced egg transport acceleration in unmated rats}

As mating increases the level of TNF- $\alpha$ in the oviductal fluid, here we determined whether administration of TNF- $\alpha$ into the oviduct of unmated rats can block the effect of $2 \mathrm{ME}$ on the egg transport. A total of 60 animals on day 1 of cycle were injected with saline into one ovarian bursa and with TNF- $\alpha 0.16,0.33$ or $3.3 \mathrm{ng} / \mu \mathrm{l}$ in the contralateral bursa, and $12 \mathrm{~h}$ later, animals were s.c. injected with $2 \mathrm{ME} 100 \mu \mathrm{g}$ or propylene glycol as vehicle. Twenty-four hours after $2 \mathrm{ME}$ or propylene glycol injections, egg transport was assessed as described in the Materials and Methods section. Replicas of this experiment are stated in Fig. 6. In order to confirm that intrabursal injection of TNF- $\alpha$ was effective, another 18 animals on day 1 of cycle were injected with saline or TNF- $\alpha 0.16 \mathrm{ng} / \mu \mathrm{l}$, and $0.5,1$ or $3 \mathrm{~h}$ later, oviducts were excised and NF-кBp50 immunoreactivity was assessed as described in the Materials and Methods section.

The results are shown in Fig. 6. In rats s.c. treated with propylene glycol (vehicle), the number of eggs recovered from the oviducts treated with saline (vehicle) was $5.2 \pm$ $0.6-5.7 \pm 1.0$ while in the contralateral oviducts treated with TNF- $\alpha$ ranged from $5.1 \pm 0.7$ to $6.8 \pm 0.7$. Treatment with $2 \mathrm{ME}$ reduced the number of eggs in the oviducts treated with saline $(1.9 \pm 0.8-2.8 \pm 0.9)$ while TNF- $\alpha$ partially blocked the $2 \mathrm{ME}$-induced egg transport acceleration in the contralateral oviducts treated with $0.16 \mathrm{ng} /$ $\mu \mathrm{l}(4.3 \pm 0.8)$ and $0.33 \mathrm{ng} / \mu \mathrm{l}(4.1 \pm 0.9)$, but not in the oviducts treated with $3.3 \mathrm{ng} / \mu \mathrm{l}(2.4 \pm 1.1)$. On the other hand, Fig. 7 shows that NF-KBp50 immunoreactivity was mainly detected in the cytoplasm of epithelial cells of the control group while TNF- $\alpha 0.16 \mathrm{ng} / \mu \mathrm{l}$ induced transient

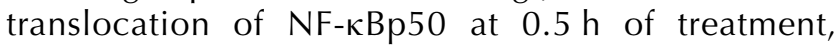
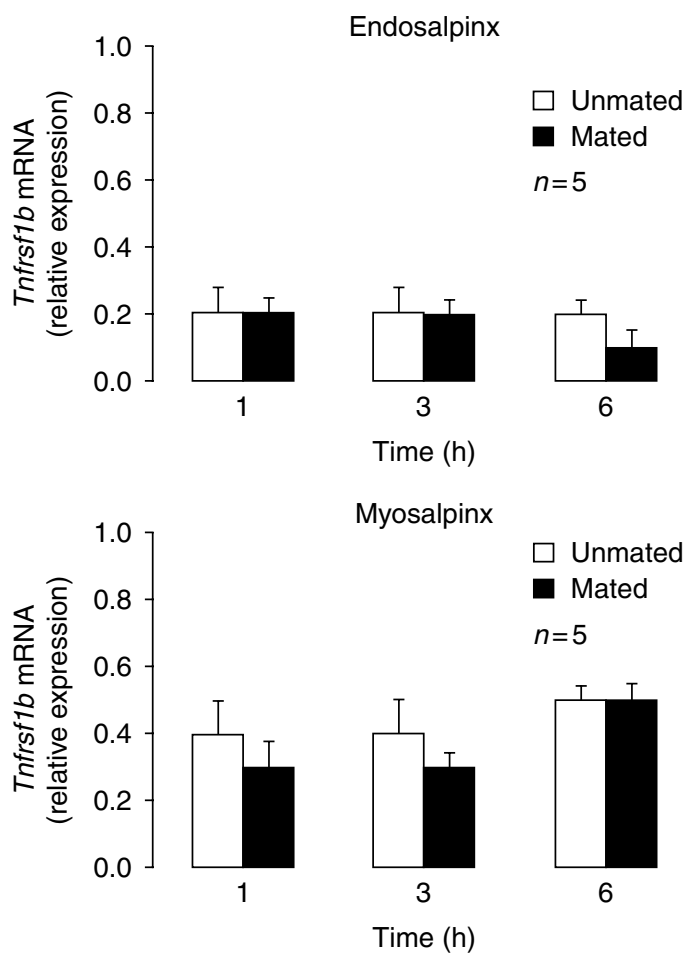

Figure 3 mRNA levels of Tnfrsf $1 b$ in the oviduct of unmated or mated rats. Rats at $0000 \mathrm{~h}$ of day 1 of the cycle were kept isolated as unmated group or caged with fertile males for 30 min as mated group, and 1, 3 or 6 h later, the endosalpinx and myosalpinx layers were separated from the oviducts to determine the Tnfrsf $1 b$ mRNA relative expression obtained through real-time PCR. The values were normalized to Gapdh. This experiment consisted of five replicates. No differences were found between treatment groups. 
$1 \mathrm{~h}$

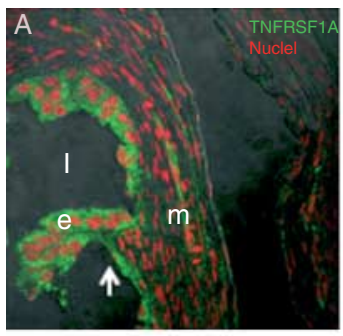

$1 \mathrm{~h}$

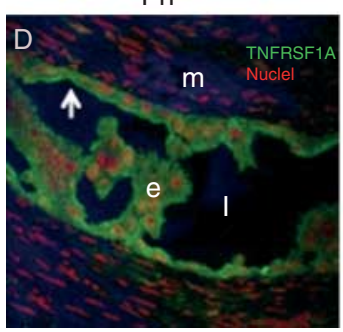

Unmated

$3 \mathrm{~h}$

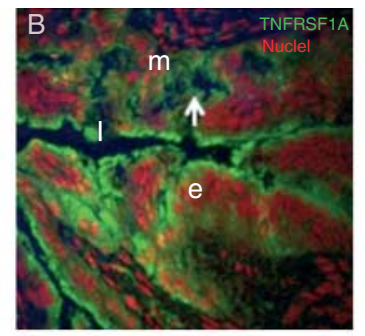

Mated

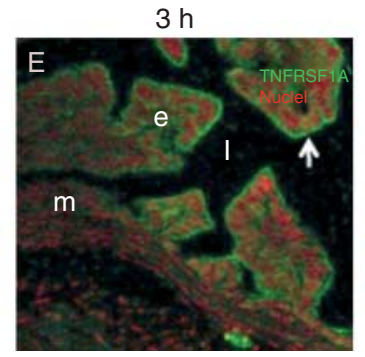

Negative control

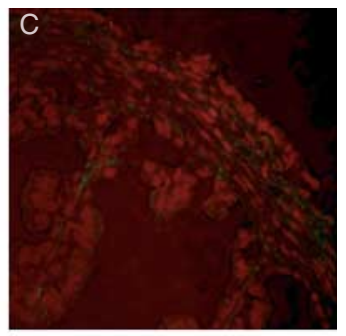

Negative control

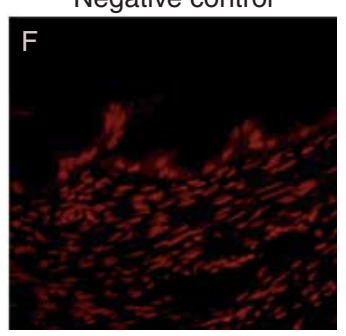

Figure 4 TNFRSF1A is expressed in the endosalpinx and myosalpinx of the oviduct of unmated or mated rats. Representative photomicrographs from rat oviducts processed by confocal microscopy. Rats at $0000 \mathrm{~h}$ of day 1 of the cycle were kept isolated as unmated group ( $\mathrm{A}$ and $\mathrm{B}$ ) or caged with fertile males for $30 \mathrm{~min}$ as mated group ( $\mathrm{E}$ and $\mathrm{D})$, and 1 or $3 \mathrm{~h}$ later, oviducts were excised to detect expression of TNFRSF1A (green). Nuclei were stained with propidium iodide (red). Arrows point to immnunoreactivity obtained in the endosalpinx and myosalpinx with no differences between all groups. This experiment consisted of three replicates. Controls of the immunoreactivity were incubated with preimmune serum (C and F). e, endosalpinx; m, myosalpinx; I, lumen. suggesting that intrabursal treatment with TNF- $\alpha$ was effective to activate its canonical signalling pathway in the oviductal epithelial cells.

\section{A selective inhibitor of $N F-\kappa B$ did not revert the effect of TNF- $\alpha$ on the $2 M E$-induced egg transport acceleration in unmated rats}

This experiment was done to establish whether inhibition of the NF- $\kappa \mathrm{B}$ signalling cascade in the oviduct blocks the effect of TNF- $\alpha$ on the egg transport acceleration following treatment with $2 \mathrm{ME}$. A total of 20 animals on day 1 of cycle were divided into the following treatment groups: i) saline plus propylene glycol; ii) saline plus $2 \mathrm{ME} 100 \mu \mathrm{g}$; TNF- $\alpha 0.16 \mathrm{ng} / \mu \mathrm{l}$ plus $2 \mathrm{ME}$ and iii) TNF- $\alpha$ plus pyrrolidine dithiocarbamate (PDCT) $75 \mu \mathrm{g} / \mu \mathrm{l}$ plus $2 \mathrm{ME}$. Propylene glycol or $2 \mathrm{ME}$ was injected $12 \mathrm{~h}$ after intrabursal injection of TNF- $\alpha$ or PDCT. Twenty-four hours after $2 \mathrm{ME}$ injection, egg transport was assessed as described in the Materials and Methods section. Replicas of this experiment are stated in Fig. 8.

\section{Unmated}

$1 \mathrm{~h}$

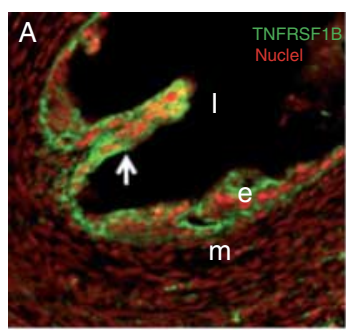

$1 \mathrm{~h}$

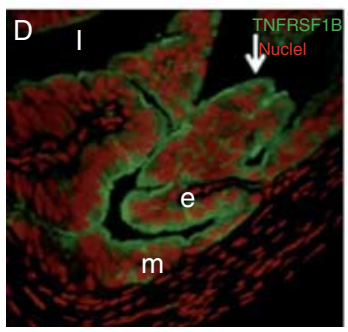

$3 \mathrm{~h}$

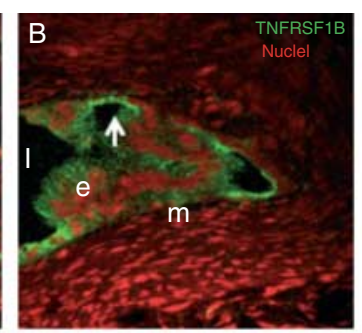

Mated

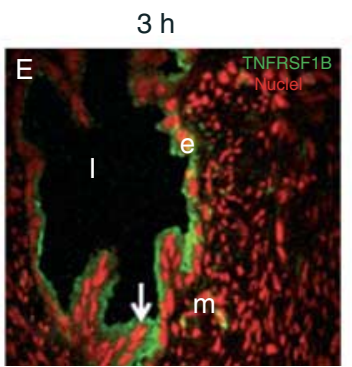

Negative control

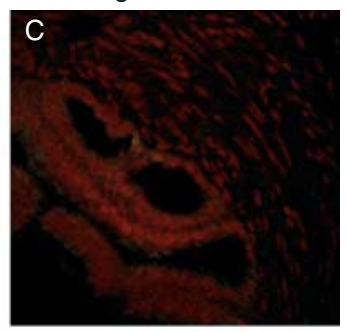

Negative control

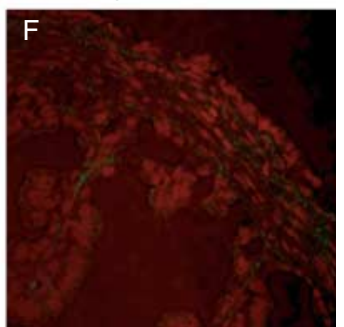

Figure 5 TNFRSF1B is expressed in the endosalpinx and myosalpinx of the oviduct of unmated or mated rats. Representative photomicrographs from rat oviducts processed by confocal microscopy. Rats at $0000 \mathrm{~h}$ of day 1 of the cycle were kept isolated as unmated group ( $\mathrm{A}$ and $\mathrm{B}$ ) or caged with fertile males for $30 \mathrm{~min}$ as mated group (E and D), and 1 or $3 \mathrm{~h}$ later, oviducts were excised to detect expression of TNFRSF1B (green). Nuclei were stained with propidium iodide (red). Arrows point to immunoreactivity obtained in the endosalpinx and myosalpinx with no differences between all groups. This experiment consisted of three replicates. Incubating samples with preimmune serum assessed the specificity of immunoreactivity. (negative controls, $\mathrm{C}$ and $\mathrm{F}$ ). e, endosalpinx; m, myosalpinx; I, lumen. 

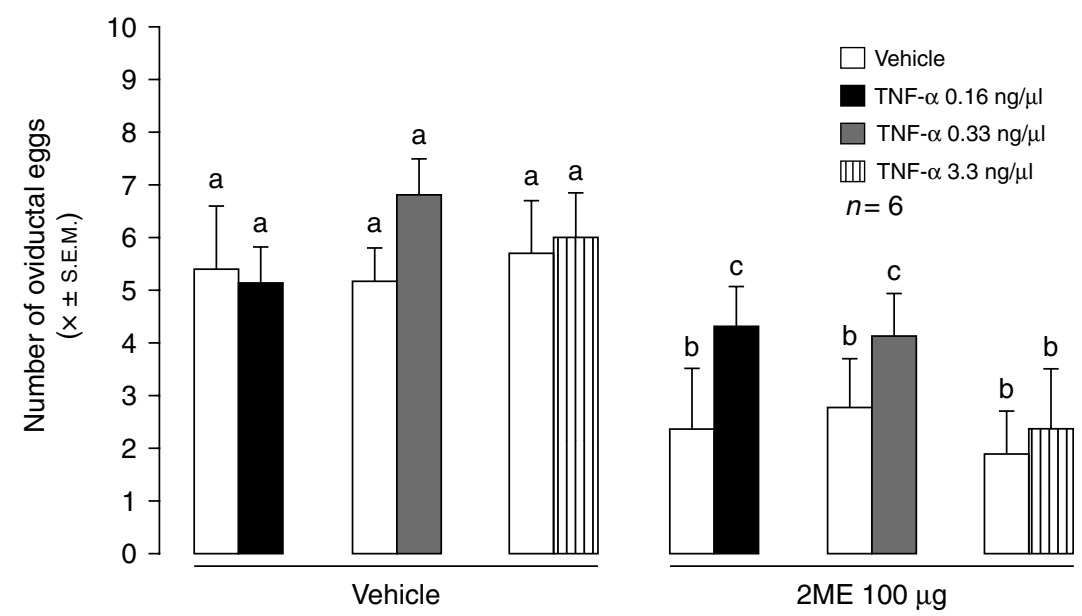

Figure 6 TNF- $\alpha$ blocks the $2 \mathrm{ME}$-induced egg
transport acceleration in unmated rats. Number of
oocytes recovered from the oviducts of unmated
rats on day 2 of the oestrous cycle. At $0060 \mathrm{~h}$ of the
day 1 of the cycle, rats were injected with saline
(vehicle) into one ovarian bursa and with TNF- $\alpha$
$0.16,0.33$ or $3.3 \mathrm{ng} / \mu \mathrm{l}$ in the contralateral bursa,
and $12 \mathrm{~h}$ later, animals were s.c. injected with $2 \mathrm{ME}$
$100 \mu \mathrm{g}$ or propylene glycol (vehicle). Twenty-four
hours after $2 \mathrm{ME}$ treatment, egg transport was
assessed. This experiment consisted of
six replicates. $\mathrm{a} \neq \mathrm{b} \neq \mathrm{c}, P<0.05$.

The results are shown in Fig. 8. The number of eggs recovered from the oviduct of the control group (saline plus propylene glycol) was $10.2 \pm 1.1$, while in the group treated with $2 \mathrm{ME}$ (saline plus $2 \mathrm{ME}$ ) was $3.2 \pm 0.8$. As previously shown, local administration of TNF- $\alpha$ (TNF- $\alpha$ plus 2ME) blocked the 2ME-induced egg transport acceleration $(10.2 \pm 1.3)$ while PDCT (TNF- $\alpha$ plus PDCT plus $2 \mathrm{ME}, 7.7 \pm 1.4$ ) did not revert this effect of TNF- $\alpha$.

\section{Discussion}

The presence of cytokines has been demonstrated in the mammalian oviduct (Fahey et al. 2005, Jiwakanon et al. 2010), an important site of gamete transport, fertilization, early embryo development and egg transport (Croxatto 1996). In contrast to other species (Hunt et al. 1993, Srivastava et al. 1996, Wijayagunawardane et al. 2003, Reyes et al. 2007), we did not find expression of TNF- $\alpha$ mRNA in the endosalpinx and myosalpinx of the rat oviduct, indicating that the regulation of the transcription of the TNF- $\alpha$ mRNA in the mammalian oviduct could be species specific. However, the number of species studied in this regard is too small to formulate a phylogenetic based algorithm describing species specificity in the presence of the transcript for TNF- $\alpha$ in the mammalian oviduct.

Although mRNA for TNF- $\alpha$ is not expressed in the rat oviductal cells, we have found that TNF- $\alpha$ protein was dramatically increased in the oviductal fluid at $3 \mathrm{~h}$ after
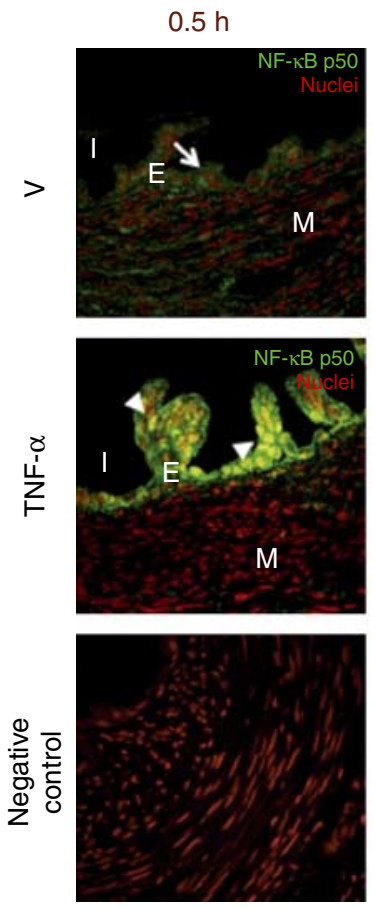

$1 \mathrm{~h}$
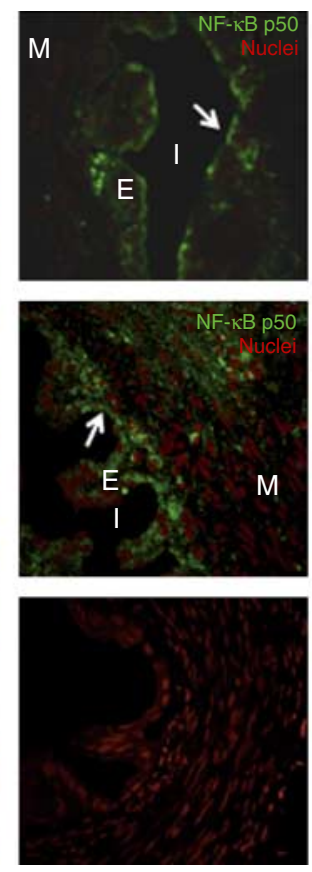

$3 \mathrm{~h}$
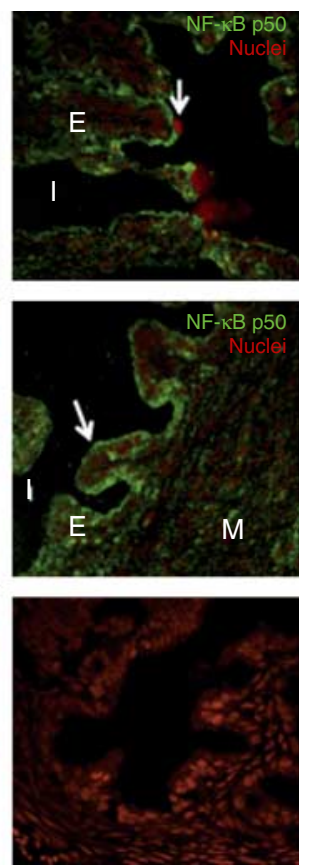

Figure $7 \mathrm{TNF}-\alpha$ induces translocation of NF- $\kappa B p 50$ from the cytoplasm into the nucleus of oviductal cells in unmated rats. Representative photomicrographs obtained from unmated rat oviducts $0.5,1$ or $3 \mathrm{~h}$ after injecting TNF- $\alpha 0.16 \mathrm{ng} / \mu \mathrm{l}$ or saline (V) intrabursal. $(n=3)$ to detect expression of NF-кBp50 (green). Nuclei were stained with propidium iodide (red). Note strong immunoreactivity of NF-kBp50 (arrowheads) in the nucleus of cells of the endosalpinx only $0.5 \mathrm{~h}$ after TNF- $\alpha$ injection. Incubating samples with preimmune serum assessed the specificity of immunoreactivity (negative control). E, endosalpinx; $M$, myosalpinx; L, lumen. 


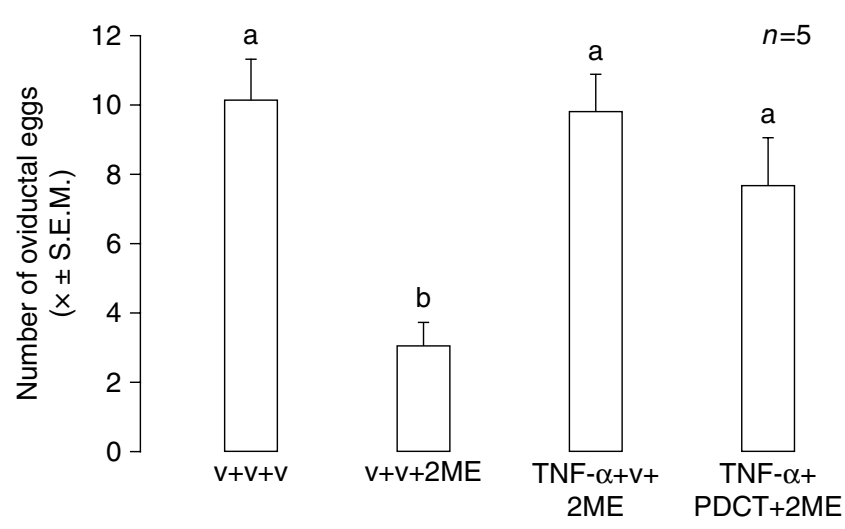

Figure 8 Inhibition of the NF- $\kappa B$ activity in the oviduct did not revert the effect of TNF- $\alpha$ on the $2 \mathrm{ME}$-induced egg transport acceleration in unmated rats. Number of oocytes recovered from the oviducts of unmated rats following intrabursal injections of TNF- $\alpha 0.16 \mathrm{ng} / \mu \mathrm{l}$ and PDCT $7.5 \mu \mathrm{g} / \mu \mathrm{l}$ or saline (V) and a s.c. injection of $2 \mathrm{ME} 100 \mu \mathrm{g}$ or propylene glycol (V) $12 \mathrm{~h}$ later. Twenty-four hours after $2 \mathrm{ME}$ treatment, egg transport was assessed. This experiment consisted of five replicates. $\mathrm{a} \neq \mathrm{b}, P<0.05$.

mating. How mating increase this cytokine in the oviductal fluid? We can speculate that some of the factors provided by mating such as the spermatozoids or sensory stimulation can interact on the uterine or vagina cells increasing the TNF- $\alpha$ release in these organs with the subsequent transport of TNF- $\alpha$ into the oviduct. Vascular connections between uterus and oviduct that facilitate the transport of several molecules along the reproductive tract may be responsible to transport TNF- $\alpha$ into the oviductal fluid (Bulletti et al. 1997). The fact that TNF- $\alpha$ levels were increased only at $3 \mathrm{~h}$ after mating can be explained by a rapid TNF- $\alpha$ degradation in the oviductal fluid and also indicate that mating has a time of latency of $3 \mathrm{~h}$ to exert its effects on the oviduct. On the other hand, TNF- $\alpha$ receptors were expressed in the oviduct, although mating did change neither the TNF- $\alpha$ receptor transcript levels nor the localization of these receptors in the rat oviduct. The presence of both TNF- $\alpha$ receptors in the endosalpinx demonstrate a compatible localization with the increased level of TNF- $\alpha$ in the oviductal fluid and reinforce our hypothesis of a role of TNF- $\alpha$ in the effect of mating on the oviductal cells.

With the purpose of demonstrating that the increased amount of TNF- $\alpha$ in the oviductal fluid observed after mating is associated with the silencing of the $2 \mathrm{ME}$ nongenomic action that accelerates oviductal egg transport, we determined whether $2 \mathrm{ME}$ accelerates egg transport in unmated rats previously treated with an intrabursal injection of TNF- $\alpha$. Our results showing that $2 \mathrm{ME}$ did no accelerate oviduct egg transport in unmated rats indicate that effectively TNF- $\alpha$ mimicked the effect of mating on the silencing of this $2 \mathrm{ME}$ nongenomic effect as previous works of our group have clearly established that $2 \mathrm{ME}$ does not accelerate egg transport in mated rats
(Parada-Bustamante et al. 2007, 2010). This suggests that TNF- $\alpha$ could be a key factor by which mating regulates the intraoviductal signalling of $\mathrm{E}_{2}$ and $2 \mathrm{ME}$ relevant to control egg transport. On the other hand, the effect of exogenous TNF- $\alpha$ occurred at small concentrations similar to the detected in the oviductal fluid, suggesting that TNF- $\alpha$ uses a receptor with high affinity to block the effect of $2 \mathrm{ME}$ on egg transport. As both TNF- $\alpha$ receptors are expressed in the rat oviduct, the identity of the receptor that participates in this effect of TNF- $\alpha$ remains to be determined.

The TNF- $\alpha$ canonical signalling pathway involves activation of the transcription factor NF- $\kappa B$ on their target cells (reviewed in Heissmeyer et al. (1999) and Aggarwal (2003)). In this context, we have also found translocation of the p50 subunit of NF- $\mathrm{BB}$ from the cytoplasm into the nucleus in oviductal epithelial cells from rats treated with TNF- $\alpha$ showing that the canonical pathway of TNF- $\alpha$ is active in the rat oviduct. However, inhibition of the NF- $\kappa B$ activity in the oviduct by administration of PDCT did not revert the effect of TNF- $\alpha$ on the $2 \mathrm{ME}$-induced egg transport acceleration. Thus, TNF- $\alpha$ acts independently of the activation of $N F-\kappa B$ to shut down the nongenomic action of $2 \mathrm{ME}$ in the rat oviduct. As PDCT prevents activation of NF- $\kappa B$ by a mechanism that involves inhibition of $\mathrm{I}-\kappa \mathrm{B}$ degradation (Liu \& Malik 1999), we cannot determine which NF-кB subunit is effectively inhibited. It has been shown that NF- $\kappa$ B does not account for all the intracellular targets of TNF- $\alpha$ (MacEwan 2002, Aggarwal 2003). For example, TNF- $\alpha$ receptors can activate the Janus kinase or p38 pathways, as well as caspase signalling (Aggarwal 2003). Furthermore, TNF- $\alpha$ stimulates adenylyl cyclase activity in human myometrial cells (Gogarten et al. 2003), and in Jurkat lymphoblastic leukemia cells, TNF- $\alpha$ induced ceramide production that leads to enhance the growth of this cell line but is unable to activate NF- $\kappa \mathrm{B}$ (Dbaibo et al. 1993). Further studies are needed to determine whether some of these alternative pathways participate in the effect of TNF- $\alpha$ on the silencing of the nongenomic action of $2 \mathrm{ME}$ in the rat oviduct.

As we have previously demonstrated that the silencing of the intraoviductal $2 \mathrm{ME}$ nongenomic effect induced by mating involves inhibition of the catechol-Omethyltransferase (COMT) activity in the oviduct (Parada-Bustamante et al. 2007), it is probable that TNF- $\alpha$ downregulate the COMT activity in the oviduct. According to this, Salama et al. (2009) have reported that in human endometrial cells, TNF- $\alpha$ increases the local biosynthesis of oestrogens while decreases the gene expression of Comt as a mechanism to prevent deleterious effects of cytokines in endometrium such as inflammation or endometrial cancer. Contrary to Salama et al. (2009), Comt expression was upregulated by TNF- $\alpha$ in human myometrial cells in preparation for uterine contractions, labour and delivery (Wentz et al. 2006). Thus, oestrogen metabolism dependent on TNF- $\alpha$ is 
influenced by the physiological context that occurs in the female reproductive tract.

There are scarce studies describing the role of TNF- $\alpha$ in he oviduct beyond inflammatory process. TNF- $\alpha$ has been associated with the cell and tissue damage observed in gonococcal salpingitis (McGee et al. 1992, Morales et al. 2006). This damage is correlated with increased TNF- $\alpha$ release by epithelium cells of the human oviduct induced by gonococcal infection (McGee et al. 1992). On the other hand, TNF- $\alpha$ stimulated secretion of the vascular endothelial growth factor by cultured human oviductal epithelial cells and stromal fibroblasts, which could be relevant to regulate oviductal fluid secretion necessary for preimplantation embryo development (Nasu et al. 2007). Moreover, preimplantation bovine embryos express and release TNF- $\alpha$ in order to regulate the oviductal motility necessary for the transport of the embryo into the uterus at the optimal time for implantation (reviewed in Wijayagunawardane \& Miyamoto (2004)). Here, we describe a new physiological function of TNF- $\alpha$ in the mammalian oviduct associated with a change in the intraoviductal $2 \mathrm{ME}$ signalling induced by mating.

In summary, these results indicate that mating increases the TNF- $\alpha$ release into the oviductal fluid, although this is not associated with changes in the expression and localization of TNF- $\alpha$ receptors in the rat oviduct. Furthermore, TNF- $\alpha$ mimics the effect of mating on the $2 \mathrm{ME}$-induced egg transport acceleration in unmated rats. It is concluded that TNF- $\alpha$ could be the signal by which mating shut down the intraoviductal $2 \mathrm{ME}$ nongenomic action that accelerates egg transport. These findings provide new evidence to understand the mechanism underlying the silencing of the $2 \mathrm{ME}$ nongenomic effect induced by mating in the oviduct and illustrate a new physiological role of TNF- $\alpha$ in the female reproductive tract.

\section{Materials and Methods}

\section{Animals}

Locally bred Sprague Dawley rats weighing 200-260 g were used. Animals were kept under controlled temperature $\left(21-24^{\circ} \mathrm{C}\right)$, and lights were on from 0700 to $2100 \mathrm{~h}$. Water and pelleted rat chows were supplied ad libitum. The phases of the oestrous cycle were determined by daily vaginal smears (Turner 1961), and all females were used after showing two consecutive 4-day cycles. To obtain unmated and mated rats, females at $0000 \mathrm{~h}$ of the day 1 of cycle were kept either isolated or caged with fertile males during $30 \mathrm{~min}$. Then, isolated rats that presented cornified cells in the vaginal smear, a cell phenotype associated with ovulation, were designated as unmated rats, and those caged with fertile males that presented cornified cells and spermatozoa in the vaginal smear were designated as mated rats. The care and manipulation of the animals were done in accordance with the ethical guidelines of the Universidad de Santiago de Chile.

\section{ELISA measurement of TNF- $\alpha$ levels}

At $0000 \mathrm{~h}$ of the day 1 of cycle, animals were kept isolated as unmated group or caged with fertile males for $30 \mathrm{~min}$ (mated group), and 1, 3 or 6 h later, oviducts were excised and flushed with $50 \mu$ saline solution in order to obtain the oviductal fluid. Levels of TNF- $\alpha$ were determined using a Rat TNF- $\alpha$ ELISA Ready-SET-Go (catalog no. 88-7340, eBioscience, San Diego, CA, USA). Protein concentration was assessed according Bradford (1976) using BSA as standard.

\section{Treatments}

Local administration of drugs

Unmated rats were injected in the ovarian bursa (intrabursal) with the drug described below. Control rats received the appropriate vehicle only. Rat recombinant TNF- $\alpha$ (BD Biosciences, San Jose, CA, USA) was injected into each ovarian bursa at a concentration of $0.16,0.33$ or $3.3 \mathrm{ng} / \mu \mathrm{l}$ in saline solution. The selective inhibitor of the NF- $\mathrm{B}$ activity PDCT, Sigma Chemical Co.) was used at a concentration of $75 \mu \mathrm{g} / \mu \mathrm{l}$ dissolved in saline solution (Liu \& Malik 1999). All treatments were given at $0600 \mathrm{~h}$ of day 1 of cycle (oestrus day).

\section{Systemic administration of $2 \mathrm{ME}$}

Unmated rats were injected s.c. with $100 \mu \mathrm{g}$ 2ME (Steraloids, Newport, RI, USA) as a single dose in an injection volume of $0.1 \mathrm{ml}$ propylene glycol. Control rats received propylene glycol alone. All treatments were given $12 \mathrm{~h}$ after local administration of drugs.

\section{Animal surgery}

Intrabursal administration of drugs, which minimizes the dose needed to affect the oviduct without systemic effects, was performed at $0600 \mathrm{~h}$ of day 1 of cycle (oestrus day) as described previously (Orihuela et al. 2001). At this time, ovulation has already taken place, so this treatment cannot affect the number of oocytes ovulated.

\section{Assessment of egg transport}

Egg transport was evaluated as previously published (Orihuela et al. 2001, 2003, 2006). Twenty-four hours after $2 \mathrm{ME}$ or vehicle treatment, animals were killed and their oviducts were flushed individually with saline. Flushing was examined under low-power magnification $(25 \times)$, and the number of eggs found was recorded.

\section{Real-time PCR}

Oviducts were dissected in endosalpinx and myosalpinx and RNA was isolated using TRIzol Reagent (Invitrogen). Total RNA $1 \mu \mathrm{g}$ of each sample was treated with DNase I Amplification grade (Invitrogen). The single-strand cDNA was synthesized by RT using the Superscript III Reverse Transcriptase First-Strand System for RT-PCR (Invitrogen), according to the 
manufacturer's protocol. The Light Cycler instrument (Roche Diagnostics $\mathrm{GmbH}$ ) was used to quantify the relative gene expression of Tnf, Tnfrsf1a or Tnfrsf1b in the oviduct; Gapdh was chosen as the housekeeping gene for load control because we have previously demonstrated that mating did not affect its expression (Ríos et al. 2007). Primers for Tnf were 5'-AGCTGTCTTCAGGCCAACAT-3' (sense) and 5'-ACAGCCTGGTCACCAAATCA-3' (antisense), Tnfrsf1a 5'-ACCAAGTGCCACAAAGGAAC-3' (sense) and 5'-CTGGAGGTAGGCACAGCTTC-3' (antisense), Tnfrsf $1 b 5^{\prime}$-ATGGTGCCTCATCTGCC-3' (sense) 5'-GGACCTGCTCATCCTTTG-3' (antisense) and for Gapdh were 5'-CTTCTCATTCCTGCTCGTGG-3' (sense) 5'-GGTATGAAATGGCAAATCGG-3' (antisense). Furthermore, liver samples of unmated rats were included as positive controls. The SYBR Green I double-strand DNA binding dye (Roche Diagnostics) was the reagent of choice for these assays. The thermal cycling conditions included an initial activation step at $95^{\circ} \mathrm{C}$ for $25 \mathrm{~min}$, followed by 40 cycles of denaturizing and annealing-amplification $\left(95^{\circ} \mathrm{C}\right.$ for $15 \mathrm{~s}$, $60{ }^{\circ} \mathrm{C}$ for $15 \mathrm{~s}$ and $72{ }^{\circ} \mathrm{C}$ for $30 \mathrm{~s}$ ) and finally one cycle of melting $\left(95-60^{\circ} \mathrm{C}\right)$. To verify specificity of the product, amplified products were subject to melting curve analysis as well as electrophoresis, and product sequencing was performed to confirm identity as described by Muscillo et al. (2001). The expression of transcripts was determined using a method previously reported (Livak \& Schmittgen 2001, Parada-Bustamante et al. 2010).

\section{Immunofluorescence}

Oviducts were fixed in cold $4 \%$ paraformaldehyde in PBS, $\mathrm{pH} 7.4-7.6$, for $2 \mathrm{~h}$ and then a sequential transfer to $10 \% \mathrm{w} / \mathrm{v}$ sucrose in PBS for $60 \mathrm{~min}$ at $4{ }^{\circ} \mathrm{C}$ and $30 \% \mathrm{w} / \mathrm{v}$ sucrose in PBS at $4{ }^{\circ} \mathrm{C}$ overnight was done. Cryostat sections, 4-6 $\mu \mathrm{m}$ thick, were placed onto gelatin-coated slides and were blocked with $1 \%$ PBS-BSA for $120 \mathrm{~min}$ and then incubated with antiTNFRSF1A (Santa Cruz Biotechnology, Santa Cruz, CA, USA), anti-TNFRSF1B (Santa Cruz Biotechnology) or anti-NF-кBp50 (Santa Cruz Biotechnology) antibody 1:50 in 1\% PBS-BSA in a humidified chamber overnight. Three PBS rinses were followed by 60 -min incubation at room temperature with secondary antibody Alexa fluor 546-conjugated goat antirabbit IgG (Invitrogen) diluted in 1\% PBS-BSA. Samples were subsequently washed with PBS, counterstained with $1 \mu \mathrm{g} / \mathrm{ml}$ propidium iodide and mounted in DABCO (Sigma). As negative controls, the primary antibody was replaced by preimmune serum. The resulting staining was evaluated using a Zeiss confocal laser-scanning microscope.

\section{Statistical analysis}

The results are presented as mean \pm S.E.M. Overall analysis was done by Kruskal-Wallis test followed by Mann-Whitney $U$ test for pair-wise comparisons when overall significance was detected. The actual $n$ value in the experiments that were performed to determine the effects of drugs on oviductal egg transport is the total number of rats used in each experimental group.

\section{Declaration of interest}

The authors declare that there is no conflict of interest that could be perceived as prejudicing the impartiality of the research reported.

\section{Funding}

This work was supported by FONDECYT (grant numbers 1080523 and 1110662) and Proyecto BASAL FBO-07.

\section{References}

Abdo M, Hisheh S, Arfuso F \& Dharmarajan A 2008 The expression of tumor necrosis factor- $\alpha$, its receptors and steroidogenic acute regulatory protein during corpus luteum regression. Reproductive Biology and Endocrinology 6 50. (doi:10.1186/1477-7827-6-50)

Aggarwal BB 2003 Signalling pathways of the TNF superfamily: a doubleedged sword. Nature Reviews. Immunology 3 745-756. (doi:10.1038/ nri1184)

Bradford MM 1976 A rapid and sensitive method for the quantitation of microgram of protein utilizing the principle of protein-dye binding. Analytical Chemistry 72 248-254.

Bulletti C, De Ziegler D, Giacomucci E, Polli V, Rossi S, Alfieri S \& Flamigni C 1997 Vaginal drug delivery: the first uterine pass effect. Annals of the New York Academy of Sciences 828 285-290. (doi:10.1111/j.1749-6632.1997.tb48549.x)

Choo KB, Hsu MC, Tsai YH, Lin WY \& Huang CJ 2011 Nuclear factor $\kappa B$ and tumor necrosis factor- $\alpha$ modulation of transcription of the mouse testis- and pre-implantation development-specific Rnf33/Trim60 gene. FEBS Journal 278 837-850. (doi:10.1111/j.1742-4658.2010.08002.x)

Croxatto HB 1996 Gamete transport. In Reproductive Endocrinology, Surgery and Technology, 3rd edn, pp 385-402. Eds EY Adashi, JA Rock\& Z Rosenwaks. Philadelphia: Lippincott-Raven Publishers.

Dbaibo GS, Obeid LM \& Hannun YA 1993 Tumor necrosis factor- $\alpha$ (TNF- $\alpha$ ) signal transduction through ceramide. Dissociation of growth inhibitory effects of TNF- $\alpha$ from activation of nuclear factor- $\mathrm{\kappa B}$. Journal of Biological Chemistry 268 17762-17766.

Erskine MS 1995 Prolactin release after mating and genitosensory stimulation in females. Endocrine Reviews 16 508-528.

Fahey JV, Schaefer TM, Channon JY \& Wira CR 2005 Secretion of cytokines and chemokines by polarized human epithelial cells from the female reproductive tract. Human Reproduction 20 1439-1446. (doi:10.1093/ humrep/deh806)

Gogarten W, Lindeman KS, Hirshman CA \& Emala CW 2003 Tumor necrosis factor $\alpha$ stimulates adenylyl cyclase activity in human myometrial cells. Biology of Reproduction 68 751-757. (doi:10.1095/ biolreprod.102.004168)

Heissmeyer V, Krappmann D, Wulczyn FG \& Scheidereit C 1999 NF-кB p105 is a target of $\mathrm{I} K \mathrm{~B}$ kinases and controls signal induction of Bcl-3-p50 complexes. EMBO Journal 18 4766-4778. (doi:10.1093/emboj/18.17. 4766)

Hunt JS, Chen HL, Hu XL \& Pollard JW 1993 Normal distribution of tumor necrosis factor- $\alpha$ messenger ribonucleic acid and protein in the uteri, placentas, and embryos of osteopetrotic (op/op) mice lacking colonystimulating factor-1. Biology of Reproduction 49 441-452. (doi:10.1095/ biolreprod49.3.441)

Jiwakanon J, Berg M, Persson E, Fossum C \& Dalin AM 2010 Cytokine expression in the gilt oviduct: effects of seminal plasma, spermatozoa and extender after insemination. Animal Reproduction Science 119 244-257. (doi:10.1016/j.anireprosci.2010.01.005)

Kapelnikov A, Zelinger E, Gottlieb Y, Rhrissorrakrai K, Gunsalus KC \& Heifetz Y 2008 Mating induces an immune response and developmental switch in the Drosophila oviduct. PNAS 105 13912-13917. (doi:10.1073/pnas.0710997105)

Lee KS, Joo BS, Na YJ, Yoon MS, Choi OH \& Kim WW 2000 Relationships between concentrations of tumor necrosis factor- $\alpha$ and nitric oxide in follicular fluid and oocyte quality. Journal of Assisted Reproduction and Genetics 17 222-228. (doi:10.1023/A:1009495913119) 
Liu SF \& Malik AB 1999 Pyrrolidine dithicarbamate prevents І-кB degradation and reduces microvascular injury induced by lipopolysaccharide in multiple organs. Molecular Pharmacology 55 658-667.

Livak KJ \& Schmittgen TD 2001 Analysis of relative gene expression data using real-time quantitative PCR and the $2(-$ Delta Delta $C(\mathrm{~T}))$ method. Methods 25 402-408. (doi:10.1006/meth.2001.1262)

MacEwan DJ 2002 TNF receptor subtype signalling: differences and cellular consequences. Cellular Signalling 14 477-492. (doi:10.1016/S08986568(01)00262-5)

Maisey K, Nardocci G, Imarai M, Cardenas H, Ríos M, Croxatto HB, Heckels JE, Christodoulides M \& Velasquez LA 2003 Expression of proinflammatory cytokines and receptors by human fallopian tubes in organ culture following challenge with Neisseria gonorrhoeae. Infection and Immunity 71 527-532. (doi:10.1128/IAI.71.1.527-532.2003)

McGee Z, Clemens C, Jensen R, Klein J, Barley L \& Gorby G 1992 Local induction of tumor necrosis factor as a molecular mechanism of mucosal damage by gonococci. Microbial Pathogenesis 12 333-341. (doi:10.1016/0882-4010(92)90096-7)

Morales P, Reyes P, Vargas M, Ríos M, Imarai M, Cardenas H, Croxatto $\mathbf{H}$, Orihuela P, Vargas R, Fuhrer J et al. 2006 Infection of human fallopian tube epithelial cells with Neisseria gonorrhoeae protects cells from tumor necrosis factor $\alpha$-induced apoptosis. Infection and Immunity 74 3643-3650. (doi:10.1128/IAI.00012-06)

Muscillo M, La Rosa G, Marianelli C, Zaniratti S, Capobianchi MR, Cantiani L \& Carducci A 2001 A new RT-PCR method for the identification of reoviruses in seawater samples. Water Research 35 548-556. (doi:10.1016/S0043-1354(00)00282-7)

Nasu K, Itoh H, Yuge A, Nishida M, Kawano Y \& Narahara H 2007 Tumor necrosis factor- $\alpha$ regulates vascular endothelial growth factor secretion by human oviductal epithelial cells and stromal fibroblasts. Fertility and Sterility 87 220-222. (doi:10.1016/j.fertnstert.2006.05.082)

O'Leary S, Jasper MJ, Warnes GM, Armstrong DT \& Robertson SA 2004 Seminal plasma regulates endometrial cytokine expression, leukocyte recruitment and embryo development in the pig. Reproduction 128 237-247. (doi:10.1530/rep.1.00160)

Orihuela PA, Ríos M \& Croxatto HB 2001 Disparate effects of estradiol on egg transport and oviductal protein synthesis in mated and unmated rats. Biology of Reproduction 65 1232-1237. (doi:10.1095/biolreprod65.4. 1232)

Orihuela PA, Parada-Bustamante A, Cortés PP, Gatica C \& Croxatto HB 2003 Estrogen receptor, cyclic adenosine monophosphate, and protein kinase $\mathrm{A}$ are involved in the nongenomic pathway by which estradiol accelerates oviductal oocyte transport in cyclic rats. Biology of Reproduction 68 1225-1231. (doi:10.1095/biolreprod.102.011395)

Orihuela PA, Parada-Bustamante A, Zúñiga LM \& Croxatto HB 2006 Inositol triphosphate participates in an oestradiol nongenomic signalling pathway involved in accelerated oviductal transport in cycling rats. Journal of Endocrinology 188 579-588. (doi:10.1677/joe.1.06448)

Orihuela PA, Zuñiga LM, Ríos M, Parada-Bustamante A, Sierralta WD, Velásquez LA \& Croxatto HB 2009 Mating changes the subcellular distribution and the functionality of estrogen receptors in the rat oviduct. Reproductive Biology and Endocrinology 7 139. (doi:10.1186/14777827-7-139)

Parada-Bustamante A, Orihuela PA \& Croxatto HB 2003 Effect of intrauterine insemination with spermatozoa or foreign protein on the mechanism of action of oestradiol in the rat oviduct. Reproduction 125 677-682. (doi:10.1530/rep.0.1250677)

Parada-Bustamante A, Orihuela PA, Ríos M, Navarrete-Gómez PA, Cuevas CA, Velásquez LA, Villalón MJ \& Croxatto HB 2007 Catechol$O$-methyltransferase and methoxyestradiols participate in the intraoviductal nongenomic pathway through which estradiol accelerates egg transport in cycling rats. Biology of Reproduction 77 934-941. (doi:10.1095/biolreprod.107.061622)

Parada-Bustamante A, Orihuela PA, Ríos M, Cuevas CA, Oróstica ML, Velásquez LA, Villalón MJ \& Croxatto HB 2010 A non-genomic signaling pathway shut down by mating changes the estradiol-induced gene expression profile in the rat oviduct. Reproduction 139 631-644. (doi:10.1530/REP-09-0218)
Parada-Bustamante A, Croxatto HB, Cárdenas H \& Orihuela PA 2012 Differential participation of endothelin receptors in estradiol-induced oviductal egg transport acceleration in unmated and mated rats. Asian Pacific Journal of Reproduction 1 17-21.

Rasmussen CA, Pace JL, Banerjee S, Phillips TA \& Hunt JS 1999 Trophoblastic cell lines generated from tumour necrosis factor receptor-deficient mice reveal specific functions for the two tumour necrosis factor receptors. Placenta 20 213-222. (doi:10.1053/plac. 1998. 0356)

Reyes PA, Vargas MF, García KP, Rubilar PS, Navarrete PA, Fuentes PM, Ríos MA, Orihuela PA, Vargas RH, Rubio VH et al. 2007 Apoptosis related genes expressed in cultured fallopian tube epithelial cells infected in vitro with Neisseria gonorrhoeae. Biological Research $\mathbf{4 0}$ 319-327. (doi:10.4067/S0716-97602007000400006)

Ríos M, Hermoso M, Sánchez TM, Croxatto HB \& Villalón MJ 2007 Effect of oestradiol and progesterone on the instant and directional velocity of microsphere movements in the rat oviduct: gap junctions mediate the kinetic effect of oestradiol. Reproduction, Fertility, and Development 19 634-640. (doi:10.1071/RD06146)

Ríos M, Parada-Bustamante A, Velásquez LA, Croxatto HB \& Orihuela PA 2011 Participation of the oviductal s100 calcium binding protein G in the genomic effect of estradiol that accelerates oviductal embryo transport in mated rats. Reproductive Biology and Endocrinology 23 69. (doi:10.1186/1477-7827-9-69)

Robertson SA 2005 Seminal plasma and male factor signalling in the female reproductive tract. Cell and Tissue Research 322 43-52. (doi:10.1007/ s00441-005-1127-3)

Salama SA, Kamel MW, Diaz-Arrastia CR, Xu X, Veenstra TD, Salih S, Botting SK \& Kumar R 2009 Effect of tumor necrosis factor- $\alpha$ on estrogen metabolism and endometrial cells: potential physiological and pathological relevance. Journal of Clinical Endocrinology and Metabolism 94 285-293. (doi:10.1210/jc.2008-1389)

Sharkey DJ, Macpherson AM, Tremellen KP \& Robertson SA 2007 Seminal plasma differentially regulates inflammatory cytokine gene expression in human cervical and vaginal epithelial cells. Molecular Human Reproduction 13 491-501. (doi:10.1093/molehr/gam028)

Srivastava MD, Lippes J \& Srivastava BI 1996 Cytokines of the human reproductive tract. American Journal of Reproductive Immunology $\mathbf{3 6}$ 157-166. (doi:10.1111/j.1600-0897.1996.tb00157.x)

Torchinsky A, Shepshelovich J, Orenstein H, Zaslavsky Z, Savion S, Carp H, Fain A \& Toder V 2003 TNF- $\alpha$ protects embryos exposed to developmental toxicants. American Journal of Reproductive Immunology 49 159-168. (doi:10.1034/j.1600-0897.2003.01174.x)

Tremellen KP, Seamark RF \& Robertson SA 1998 Seminal transforming growth factor $\beta 1$ stimulates granulocyte-macrophage colony-stimulating factor production and inflammatory cell recruitment in the murine uterus. Biology of Reproduction 58 1217-1225. (doi:10.1095/biolreprod58.5.1217)

Turner CD 1961 Endocrinology of the ovary. In General Endocrinology, 3rd edn, pp 365-409. Ed CD Turner. Philadelphia: WB Saunders Company.

Wentz MJ, Jamaluddin M, Garfield RE \& Al-Hendy A 2006 Regulation of catechol-O-methyltransferase expression in human myometrial cells. Obstetrics and Gynecology 108 1439-1447. (doi:10.1097/01.AOG. 0000243775.73788.11)

Wijayagunawardane MP \& Miyamoto A 2004 Tumor necrosis factor $\alpha$ system in the bovine oviduct: a possible mechanism for embryo transport. Journal of Reproduction and Development 50 57-62. (doi:10.1262/jrd.50.57)

Wijayagunawardane MP, Gabler C, Killian G \& Miyamoto A 2003 Tumor necrosis factor $\alpha$ in the bovine oviduct during the estrous cycle: messenger RNA expression and effect on secretion of prostaglandins, endothelin-1, and angiotensin II. Biology of Reproduction 69 1341-1346. (doi:10.1095/biolreprod.103.017327)

Received 2 October 2012

First decision 29 October 2012

Accepted 12 November 2012 